\title{
Invitro-Antioxidant activity of the seed and leaf extracts of syzygium cumini
}

\author{
Lekha K Nair ${ }^{1}$, Maleeka Begum ${ }^{2}$, Geetha. $\mathrm{S}^{2}$ \\ ${ }^{I}$ Ph.D Scholar, R\&D, Bharathiar University, Coimbatore, Tamilnadu, India \\ ${ }^{2}$ Deparment of Biotechnology, Sri Krishna College of Arts and Science, Coimbatore, Tamilnadu, India
}

\begin{abstract}
The present research was subjected to screen invitro antioxidant activity of the seed and leaf extract of Syzygium cumini. The antioxidant activity was determined by in vitro methods such as 2,2-diphenyl-1picrylhydrazyl (DPPH) scavenging assay, ABTS Assay, Total antioxidant activity (Phosphomolybdic acid method), Nitric oxide radical scavenging, Ferric reducing antioxidant power (FRAP) assay, Hydroxyl radical scavenging activity, Total Reducing antioxidant potential, Reducing power. The extract showed significant antioxidant activity in all antioxidant assays when compared to ascorbic acid. The results of this research work are promising thus indicating the utilisation of the seed and leaf of Syzygium cumini as a significant source of natural antioxidants
\end{abstract}

Keywords: Antioxidant activity, ABTS, DPPH, FRAP, NOS, TRAP, Total antioxidant activity, Reducing power, Hydroxyl radical scavenging activity, Syzygium cumini.

\section{INTRODUCTION}

Plants are the potential source of natural antioxidants. Natural antioxidants or phytochemical antioxidants are the secondary metabolites of plants (Walton, and Brown, 1999). Antioxidant agents like tannins, flavonoids, phenols, polyphenols, and nitric acid, scavengers of free radicals such as peroxidase, hydrogen peroxidase or lipid peroxyl thus inhibits the oxidative mechanism that lead to degenerative diseases. Antioxidants are found in all parts of plants such as bark, stalks, leaves, fruits, roots, flowers, pods and seeds. The most effective components seem to be flavonoids and phenolic compound of many plant raw materials, particularly in herbs, seeds and fruits. Increasing the antioxidants intake can prevent diseases and lower the health problems. Research is increasingly showing that antioxidant rich foods, herbs reap health benefits.

Syzygium cumini seeds are extensively used for various ailments such as anti-inflammatory, hypolipidaemic, antidiabetic and antioxidant, neuroprotective and recently it has been reported (Patel et al, 2010) for the DNA protection against radiation. Although the syzygium cumini seeds were used for several biological activities; the possible cardioprotective (Oliver, 1980) reported the effect of the syzygium cumini (Jamun) seeds against the DOX induced acute myocardial stress in rats. Phytochemicals such as saponins, terpenoids, flavonoids, tannins, steroids and alkaloids have antiinflammatory effects .Glycosides, flavaloids, tannins and alkaloids have hypoglycemic activities. Syzygium cumini might be responsible for its high antioxidant activity. This activity was observed when an increase in levels of plasma glucose, vitamin-E, ceruloplasmin, lipid peroxides and a decrease in levels of vitamin $\mathrm{C}$ and glutathione observed in diabetic rats, recover back to the normal levels after treatment with Syzgium cumi seed kernel extract (Warrier et al, 1996). Histopathological studies also promise its protective effect on pancreatic $\beta$-cells. Ethanolic extract of Syzgium cumini seed kernel also lowering the thiobarbituric acid reactive substance (TBARS) and increased in reduced glutathione (GSH), superoxide dismutase (SOD) and catalyse (CAT).

\subsection{Collection of Plant materials}

\section{MATERIALS AND METHODS}

The fully mature Syzygium cumini Skeels leaves and seeds were collected in sep 2012 from Saravanampatty in Coimbatore District of Tamil Nadu, India from a single tree. The seed was identified and authenticated wide voucher specimen by the college afflicted to KMCH College of Pharmacy, Coimbatore. (10)

\subsection{Preparation of extracts}

The Syzygium cumini Skeels fruits were first washed well and pulp was removed from the seeds. Seeds were washed several times with distilled water to remove the traces of pulp from the seeds. The seeds and leaves were dried at room temperature and coarsely powdered. The powders were taken equally and extracted with hexane to remove lipids. It was then filtered and the filtrate was discarded. The residue was subjected to successive solvent extraction with Petroleum ether, Ethyl acetate, Methanol and Water using Soxhlet extraction method, aqueous extract was prepared by cold maceration process. The Plant Extracts Were Concentrated Using Rotary Flash Vaporator (Buchi, Switzerland) And Stored In Desicator. 


\subsection{INVITRo-ANTIOXIDANT ACTIVITY \\ 1.3.1. ABTS ASSAY}

The scavenging activity of the test sample was tested using ABTS+ assay. The method was described by Re et al., 1999 with a slight modification. The ABTS+ radical solution was prepared by mixing $14 \mathrm{mM}$ ABTS stock solution with $4.9 \mathrm{mM}$ ammonium per sulphate and incubated $16 \mathrm{~h}$ in the dark at room temperature until the reaction was stable. The absorbance of the ABTS+ solution was equilibrated to $0.70 \pm 0.02$ by diluting with ethanol at room temperature. To $1 \mathrm{ml}$ of the ABTS+ solution various concentration of the test sample (20$100 \mu \mathrm{g} / \mathrm{ml}$ ) was added. The absorbance was measured at $734 \mathrm{~nm}$ after 6 minutes. The percentage inhibition of absorbance was calculated and plotted as a function of the concentration of standard and sample to determine the antioxidant concentration. Ascorbic acid was used as a standard.

\subsubsection{Total ANTIOXIDANT aCtivity (Phosphomolybdic aCid Method)}

The antioxidant activity of the sample was evaluated by the transformation of Mo (VI) to Mo (V) to form phosphomolybdenum complex. An aliquot of $0.2 \mathrm{ml}$ of sample solution $(20-100 \mu \mathrm{g} / \mathrm{ml})$ was combined in a vial with $2 \mathrm{ml}$ of reagent solution $(0.6 \mathrm{M}$ sulphuric acid, $28 \mathrm{mM}$ sodium phosphate and $4 \mathrm{mM}$ ammonium molybdate). The vials were capped and incubated in a water bath at $95^{\circ} \mathrm{C}$ for $30 \mathrm{~min}$. After the samples had cooled to room temperature, the absorbance of the mixture was measured at $695 \mathrm{~nm}$ against a blank. The antioxidant activity was expressed relative to that of ascorbic acid.

\subsubsection{FRAP ASSAY}

A modified method of Benzie and Strain et al., (1996) was adopted for the FRAP assay. The stock solutions included $300 \mathrm{mM}$ acetate buffer, $\mathrm{pH} 3.6,10 \mathrm{mM}$ TPTZ (2, 4, 6-tripyridyl-Striazine) solution in $40 \mathrm{mM}$ $\mathrm{HCl}$ and $20 \mathrm{mMFeCl} 3.6 \mathrm{H} 2 \mathrm{O}$. The fresh working solution was prepared by mixing $25 \mathrm{ml}$ acetate buffer, $2.5 \mathrm{ml}$ TPTZ and $2.5 \mathrm{ml} \mathrm{FeCl} 3.6 \mathrm{H} 2 \mathrm{O}$. The temperature of the solution was raised to $37^{\circ} \mathrm{C}$ before using. Plant extracts $(20-100 \mu \mathrm{g} / \mathrm{ml})$ were allowed to react with $900 \mu$ l of FRAP solution and the solution was made upto $1 \mathrm{ml}$ with methanol. After 4 minutes readings of the colored product (Ferrous tripyridyltriazine complex) were taken at $593 \mathrm{~nm}$. The standard curve was linear between 200 and $1000 \mu \mathrm{M}$ FeSO4. Results are expressed in $\mu \mathrm{M}(\mathrm{Fe}$ (II) /g dry mass and compared with that of ascorbic acid.

\subsubsection{NITRIC OXIDE RADICAL SCAVENGING}

Nitric oxide was generated from sodium nitro prusside in aqueous solution at physiological $\mathrm{pH}$, which interacts with oxygen to produce nitric ions, which may be determined by the Griess Illosvoy reaction. $2 \mathrm{ml}$ of $10 \mathrm{mM}$ sodium nitro prusside $0.5 \mathrm{ml}$ phosphate buffer saline $(\mathrm{pH} 7.4)$ was mixed with $0.5 \mathrm{ml}$ of sample at different concentrations and the mixture incubated at $25^{\circ} \mathrm{C}$ for 150 minutes. From the incubated mixture $1.5 \mathrm{ml}$ was taken out and added into $1.5 \mathrm{ml}$ of griess reagent ( $1 \%$ sulphanilamide, $2 \%$ o-phosphoric acid, $0.1 \%$ napthyl ethylene diamine di $\mathrm{Hcl}$ ) and incubated at room temperature for $5 \mathrm{mins}$. The absorbance of the mixture at $546 \mathrm{~nm}$ was measured with a spectrophotometer.

\subsubsection{REDUCING POWER}

The Fe ${ }^{+}$-reducing power of the extract was determined by the method of Oyaizu et al., 1986 with a slight modification. Different concentrations $(20-100 \mu \mathrm{g} / \mathrm{ml})$ of the extract $(1 \mathrm{ml})$ were mixed with $2.5 \mathrm{ml}$ phosphate buffer $(0.2 \mathrm{M}, \mathrm{pH} 6.6)$ and $2.5 \mathrm{ml}$ potassium hexa cyanoferrate $(1 \%)$, followed by incubation at $50^{\circ} \mathrm{C}$ in a water bath for $20 \mathrm{~min}$. After incubation, $2.5 \mathrm{ml}$ of TCA (10\%) was added to terminate the reaction. The upper portion of the solution $(2.5 \mathrm{ml})$ was mixed with $2.5 \mathrm{ml}$ distilled water, and $0.5 \mathrm{ml} \mathrm{FeCl3solution}(0.1 \%)$ was added. The reaction mixture was left for $10 \mathrm{~min}$ at room temperature and the absorbance was measured at $700 \mathrm{~nm}$ against an appropriate blank solution. A higher absorbance of the reaction mixture indicated greater reducing power. Ascorbic acid was used as a positive control (Oyaizu,2003)

\subsubsection{DPPH ASSAY}

This was assayed as described by Elizabeth and Rao (1990).the reaction mixture contained methanol$50 \mathrm{ml}$. DPPH (diphenyl 2-picryl hydrazyl radical) $0.3 \mathrm{mM}$. $1 \mathrm{ml}$ of $0.3 \mathrm{mM} \mathrm{DPPH} \mathrm{in} \mathrm{methanol} \mathrm{was} \mathrm{added} \mathrm{to} 100 \mu 1$ of compound with concentrations ranging from $20 \mu \mathrm{g}$ to $100 \mu \mathrm{g}$.DPPH solution with methanol was used as a positive control and methanol alone acted as a blank. When DPPH reacts with antioxidants in the sample, it was reduced and the color changed from deep violet to light yellow. This was measured at $517 \mathrm{~nm}$.

\subsubsection{HYDROXYL RADICAL SCAVENGING ACTIVITY}

The scavenging activity for hydroxyl radicals recommended with major changes. Reaction mixture contained $0.6 \mathrm{ml} 1$ of $1.0 \mathrm{mM}$ Deoxy ribose, $0.4 \mathrm{ml}$ of $0.2 \mathrm{mM}$ Phenyl hydrazine, $0.6 \mathrm{ml}$ of $10 \mathrm{mM}$ phosphate buffer ( $\mathrm{pH}$ 7.4). It was incubated for one hour at room temperature. Then add $1 \mathrm{ml}$ of $2-8 \%$ TCA, $1 \mathrm{ml}$ of $1 \%$ 
TBA and $0.4 \mathrm{ml}$ of extract at various concentrations and kept in water bath for 20 minutes. The absorbance of the mixture at $532 \mathrm{~nm}$ was measured with a spectrophotometer. The hydroxyl radical scavenging activity was calculated

\subsubsection{TOTAL REDUCING ANTIOXIDANT POTENTIAL}

The reaction mixture contains $0.35 \mathrm{ml}$ of 27 , dichloro flurecein diacetate ( $1 \mathrm{mM}$ in ethanol), $1.75 \mathrm{ml}$ of $0.01 \mathrm{~N} \mathrm{NaOH}$ incubated for 20 minutes at room temperature. $17.9 \mathrm{ml}$ of $25 \mathrm{mM}$ sodium phosphate buffer ( $\mathrm{pH}$ 7.2). The upper portion of the solution $(150 \mu \mathrm{l})$ different concentration of plant extract was added $(20-100 \mu \mathrm{g} / \mathrm{ml})$ and made upto $0.5 \mathrm{ml}$ with methanol. $25 \mu \mathrm{l}$ of $56 \mathrm{mM}$ was added to initiate the reaction. The absorbance was measured at 490nm against the corresponding blank samples. Ascorbic acid was used as a reference standard.

\section{FIGURES AND TABLES}

In the present study the extracts prepared from dried parts of the plant Syzygium cumini were subjected to Pharmacognostical, Preliminary, Phytochemical anaylsis and Antimicrobial and Invitro-Antioxidant Acitivity study was done.

Pharmacognostical Studies

Table 1 reveals the $\%$ extractability with the various solvents used for the study. Ethyl acetate extended higher $\%$ extractability (1.2\%). The other chemical constituents, such as total ash, acid insoluble and water soluble ash value and loss of moisture content are also depicted in the same table. Table 2 reveals the physical nature of the ethyl acetate extract of S.cumini.

Phytochemical Studies

Table 3 depicts the result of qualitative analysis of Ethyl acetate extract of S.cumini. The study confirms the presence of Alkaloids and Glycosides to a larger extent. Table 4 reveals the $R_{f}$ value of the phytochemical constituents with respective solvent system.

Invitro-Antioxidant Activity

In the present work, the Ethyl acetate extract of Syzygium cumini was evaluated for their DPPH Radical scavenging activity. It was observed that the DPPH Radical scavenging activity of S.cumini was as comparable to that of standard ascorbic acid (Table 05 and Figure 1).

Total antioxidant capacity of the Ethyl acetate extract of Syzygium cumini, expressed as the number of gram equivalents of ascorbic acid. Ethyl acetate extract of S.cumini showed higher total antioxidant capacity when compare to standard Ascorbic acid (Table 6 and Fig 2).

Table 7 and Figure 3 shows that the FRAP values of the Ethyl acetate extract of Syzygium cumini are significantly lower than that of ascorbic acid.Table 8 reveals the \% of reducing power assay of Ethyl acetate extract of S.cumini against standard ascorbic acid (Table 8 and Fig 4).

Hydroxyl radical scavenging activity was comparatively lower than that of standard ascorbic acid (Table 9 and Figure 5). The scavenging activity of ABTS radical assay showed that Ethyl acetate extract had higher activity when compared to ascorbic acid (Table 10 and Fig 6).

Percent inhibition of the nitrite oxide generated is measured by comparing the absorbance values of control and test preparations and ascorbic acid can be used as a positive control. The \% inhibition was increased with increasing concentration of the extract. The syzygium cumini Ethyl acetate extract had better reducing power (Table 11 and Fig 7).The Total reducing antioxidant potential activity was evaluated. It was observed that Ethyl acetate extract had higher activity when compared to ascorbic acid (Table 12 and Fig 8).

Table-1- Physicochemical Parameters Value of S.cumini Ethyl acetate extract.

\begin{tabular}{|l|c|}
\hline Parameters & \% of w/w \\
\hline Extractive & \\
\hline Petroleum ether & $0.6 \%$ \\
\hline Chloroform & $1 \%$ \\
\hline Ethyl acetate & $1.2 \%$ \\
\hline Methanol & $0.07 \%$ \\
\hline Water & $1.16 \%$ \\
\hline Ash value & \\
\hline Total ash & $25 \%$ \\
\hline Acid insoluble ash value & $2.5 \%$ \\
\hline Water soluble ash value & $5.25 \%$ \\
\hline $\begin{array}{l}\text { Moisture content } \\
\text { Loss of moisture content }\end{array}$ & $0.1 \mathrm{gram}$ \\
\hline
\end{tabular}


Table-2-The physical characters for Ethyl acetate S.cumini extract.

\begin{tabular}{|l|l|}
\hline Parameters & Ethyl acetate extract \\
\hline Color & Dark greenish \\
\hline Odor & No odor \\
\hline Taste & Characteristic \\
\hline Consistency & Viscous \\
\hline
\end{tabular}

Table 3 The qualitative analysis of the Ethyl acetate extract of $\underline{S} . \underline{\text { cumini }}$

\begin{tabular}{|l|l|c|}
\hline S.No & Phytoconsituents & Ethyl acetate extract of S.cumini \\
\hline 1 & Alkaloids & ++ \\
2 & Glycosides & ++ \\
3 & Sterols & + \\
4 & Tannin & + \\
5 & Resins & + \\
6 & Carbohydrates & + \\
7 & Protein \& Amino acids & + \\
8 & Saponins & - \\
9 & Gum \&mucilage & + \\
10 & Flavaloids & - \\
11 & Vitamin-C & + \\
\hline
\end{tabular}

+=Present; ++=Moderately present; +++=Appreciable amount; - =Absent.

Table- 4-TLC phytoconstituents analysis of Ethyl acetate extract of S.cumini.

\begin{tabular}{|c|c|c|c|c|c|c|}
\hline $\begin{array}{l}\text { S.N } \\
0\end{array}$ & Compounds & Solvent system & Detecting agent & $\begin{array}{l}\text { Solvent } \\
\text { front }\end{array}$ & $\begin{array}{l}\text { No of } \\
\text { spots }\end{array}$ & $\begin{array}{l}\mathrm{Rf} \\
\text { value }\end{array}$ \\
\hline 1 & Alkaloids & $\begin{array}{l}\text { Tolune:Ethyl acetate : } \\
\text { Diethyl amine( } 7: 2: 1)\end{array}$ & $\begin{array}{l}\text { Ultra violet } \\
\text { Spectroscopy }\end{array}$ & 3.9 & $\begin{array}{l}1 \\
2 \\
3 \\
\end{array}$ & $\begin{array}{l}1.20 \\
2.00 \\
2.30 \\
\end{array}$ \\
\hline 2 & Glycosides & Benzene: Ethanol(19:2) & $\begin{array}{l}\text { Ultra violet } \\
\text { Spectroscopy }\end{array}$ & 4.8 & $\begin{array}{l}1 \\
2 \\
3 \\
\end{array}$ & $\begin{array}{l}2.2 . \\
3.67 \\
4.49 \\
\end{array}$ \\
\hline 3 & Flavaloids & Tolune:Ethyl acetate $(93: 7)$ & $\begin{array}{l}\text { Ultra violet } \\
\text { Spectroscopy }\end{array}$ & 5.8 & $\begin{array}{l}1 \\
2 \\
3\end{array}$ & $\begin{array}{l}2.41 \\
3.44 \\
4.56\end{array}$ \\
\hline 4 & Steroids & $\begin{array}{lll}\begin{array}{l}\text { Petroleum } \\
\text { acetate }(7: 3)\end{array} & \text { Ether: } & \text { Ethyl } \\
\end{array}$ & $\begin{array}{l}\text { Ultra violet } \\
\text { Spectroscopy }\end{array}$ & 4.3 & $\begin{array}{l}1 \\
2\end{array}$ & $\begin{array}{l}0.94 \\
1.54\end{array}$ \\
\hline 5 & Triterprinoids & $\begin{array}{l}\text { Chloroform:Ethyl } \\
\text { acetate }(9: 1)\end{array}$ & $\begin{array}{l}\text { Ultra violet } \\
\text { Spectroscopy }\end{array}$ & 4.5 & 1 & 2.47 \\
\hline
\end{tabular}

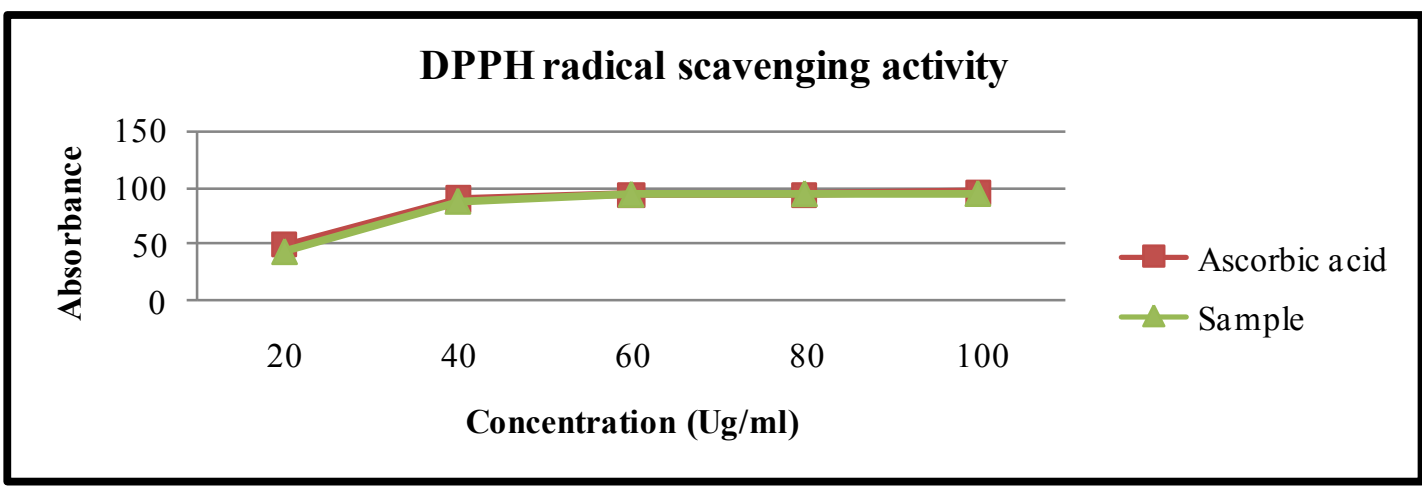

Figure 1-DPPH radical scavenging activity of Ethyl acetate extract of S.cumini

Table 5- Percentage of DPPH radical scavenging activity of Ethyl acetate extract of S.cumini

\begin{tabular}{|l|c|c|c|}
\hline S.no & \multirow{2}{*}{$\begin{array}{c}\text { Concentration } \\
\text { (ug/ml) }\end{array}$} & \% of inhibion & sample \\
\cline { 3 - 4 } & 20 & Ascorbic acid & 44.2 \\
\hline 1 & 40 & 49.4 & 87.5 \\
\hline 2 & 60 & 90.2 & 93.4 \\
\hline 3 & 80 & 93.3 & 94.0 \\
\hline 4 & 100 & 93.9 & 94.2 \\
\hline 5 & & 95.8 & \\
\hline
\end{tabular}




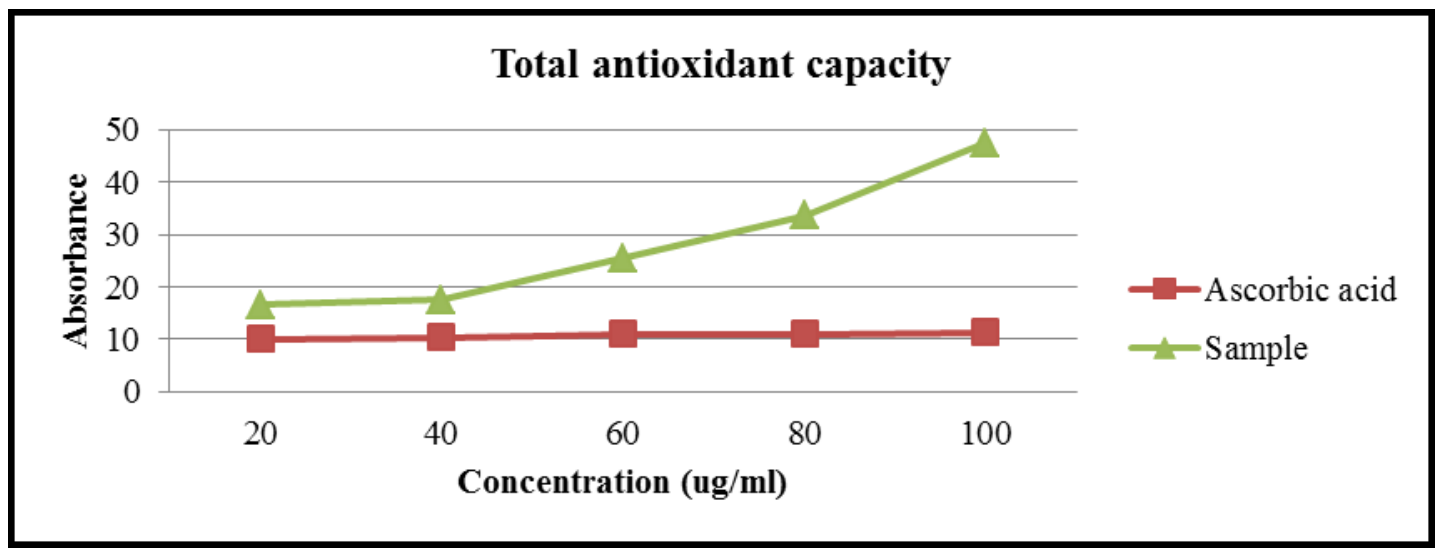

Figure 2-Total antioxidant capacity of Ethyl acetate extract of S.cumini

Table 6- Percentage of Total antioxidant capacity of Ethyl acetate extract of S.cumini

\begin{tabular}{|l|c|c|c|}
\hline S.No & $\begin{array}{l}\text { Concentration } \\
\text { (ug/ml) }\end{array}$ & \multicolumn{2}{|c|}{ \% total antioxidant capacity } \\
\hline & & Ascorbic acid & sample \\
\hline 1 & 20 & 10.0 & 16.6 \\
\hline 2 & 40 & 10.4 & 17.5 \\
\hline 3 & 60 & 11.0 & 25.6 \\
\hline 4 & 80 & 11.1 & 33.6 \\
\hline 5 & 100 & 11.4 & 47.5 \\
\hline
\end{tabular}

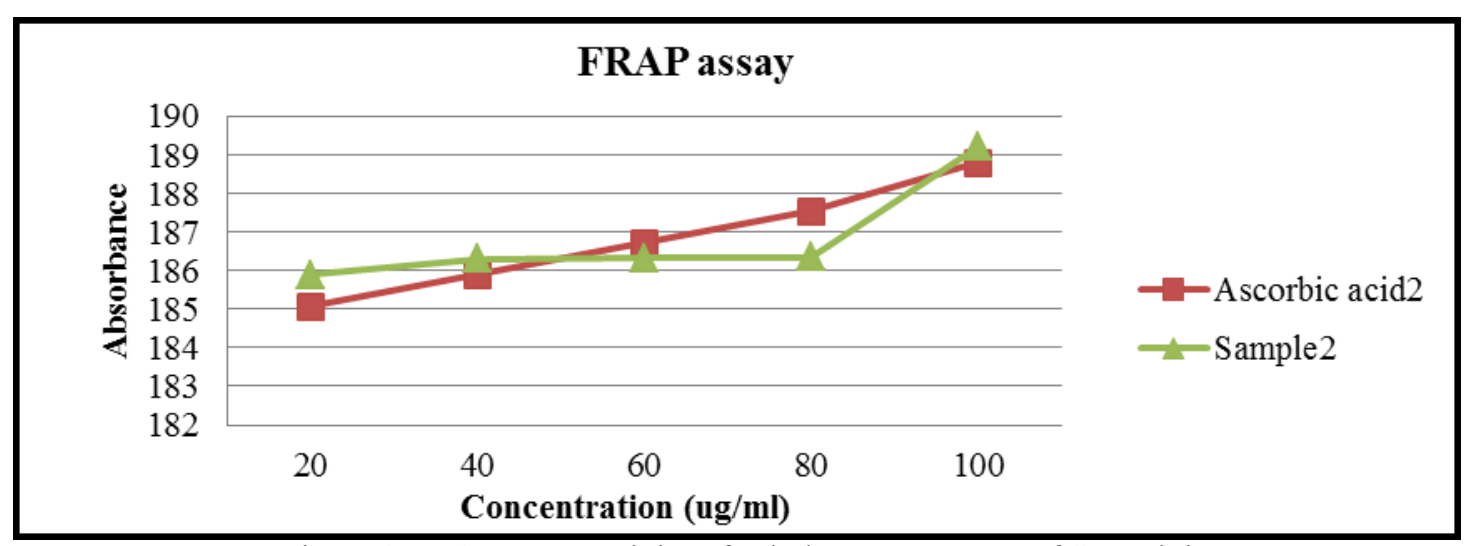

Figure 3-FRAP assay activity of Ethyl acetate extract of S.cumini

Table 7- Percentage of FRAP assay activity of Ethyl acetate extract of S.cumini

\begin{tabular}{|c|c|c|c|}
\hline S.No & \multirow{2}{*}{$\begin{array}{l}\text { Concentration } \\
\text { (ug/ml) }\end{array}$} & \% of FRAP assay activity \\
\cline { 2 - 4 } & 20 & Ascorbic acid & sample \\
\hline 1 & 40 & 185.06 & 185.89 \\
\hline 2 & 60 & 185.89 & 186.3 \\
\hline 3 & 80 & 186.72 & 186.32 \\
\hline 4 & 100 & 187.55 & 186.35 \\
\hline 5 & 188.79 & 189.21 \\
\hline
\end{tabular}




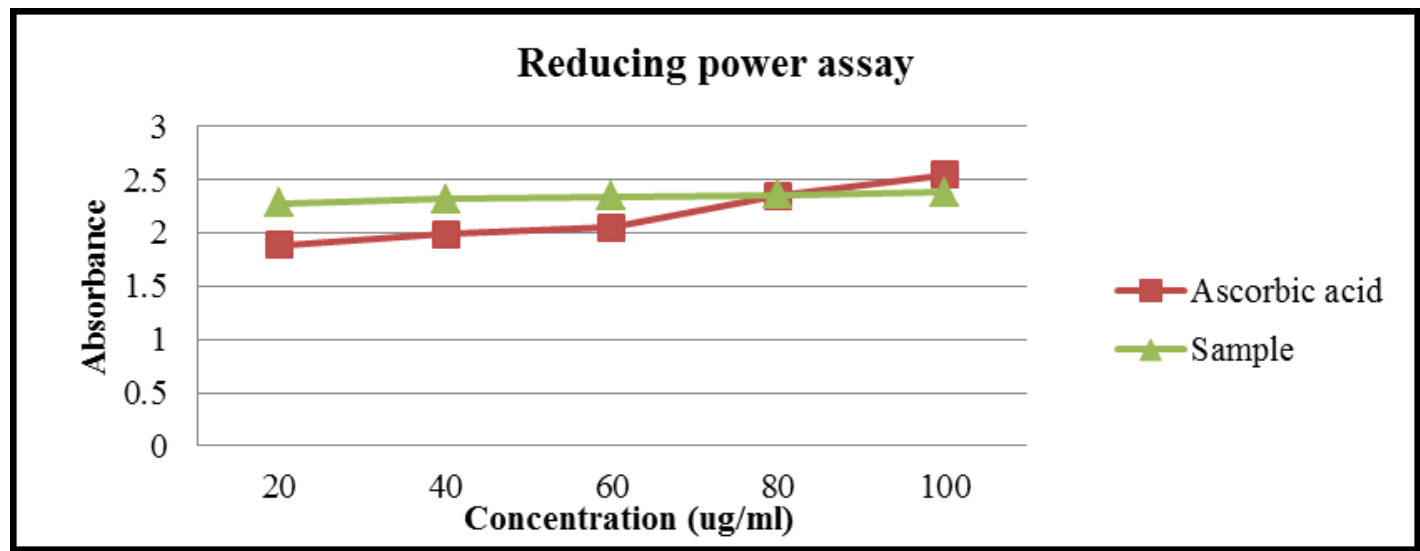

Figure 4-Reducing power assay of Ethyl acetate extract of S.cumini

Table 8-Percentage of Reducing power assay of Ethyl acetate extract of S.cumini

\begin{tabular}{|c|c|c|c|}
\hline \multirow{2}{*}{ S.No } & \multirow{2}{*}{$\begin{array}{l}\text { Concentration } \\
\text { (ug/ml) }\end{array}$} & \multicolumn{2}{|c|}{ \% of reducing power } \\
\cline { 3 - 4 } & 20 & Ascorbic acid & sample \\
\hline 1 & 40 & 1.89 & 2.28 \\
\hline 2 & 60 & 2.99 & 2.32 \\
\hline 3 & 80 & 2.35 & 2.34 \\
\hline 4 & 100 & 2.55 & 2.36 \\
\hline 5 & & 2.38 \\
\hline
\end{tabular}

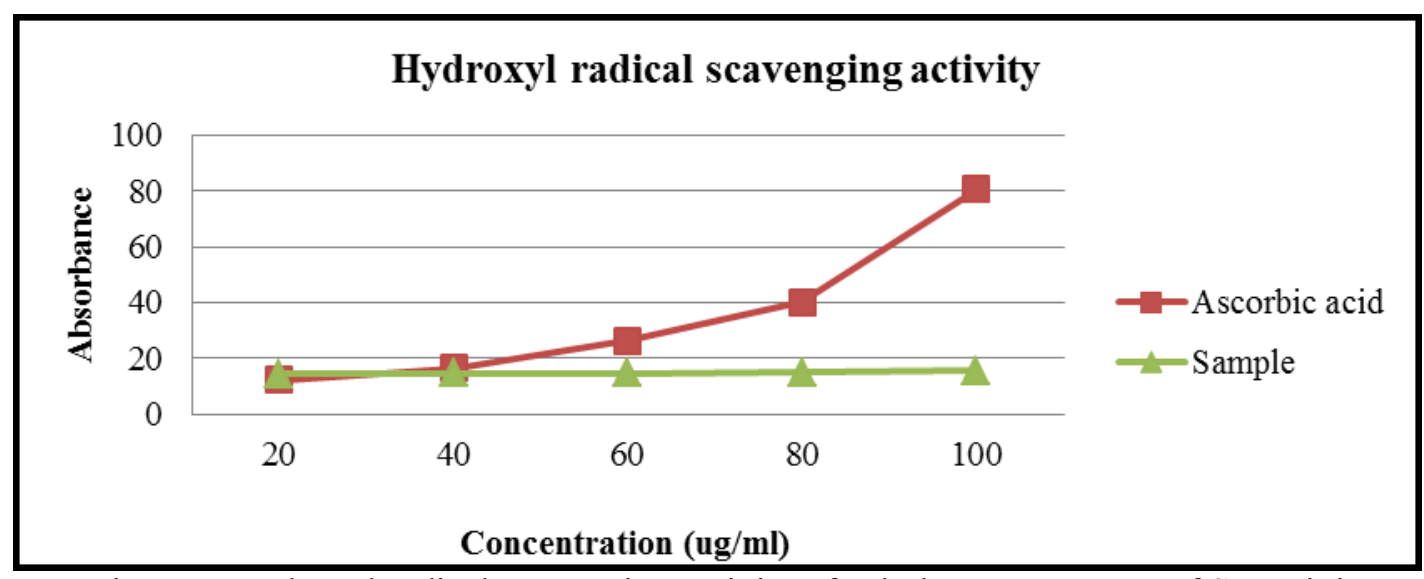

Figure 5-Hydroxyl radical scavenging activity of Ethyl acetate extract of S.cumini

Table 9- Percentage of Hydroxyl radical scavenging activity of Ethyl acetate extract of S.cumini

\begin{tabular}{|c|c|c|c|}
\hline S.No & \multirow{2}{*}{$\begin{array}{l}\text { Concentration } \\
\text { (ug/ml) }\end{array}$} & \multicolumn{2}{|c|}{ \% of - Hydroxyl radical scavenging activity } \\
\cline { 3 - 4 } & & Ascorbic acid & sample \\
\hline 1 & 20 & 12.2 & 14.2 \\
\hline 2 & 40 & 16.3 & 14.5 \\
\hline 3 & 60 & 26.2 & 14.7 \\
\hline 4 & 80 & 40.0 & 14.9 \\
\hline 5 & 100 & 80.5 & 15.4 \\
\hline
\end{tabular}




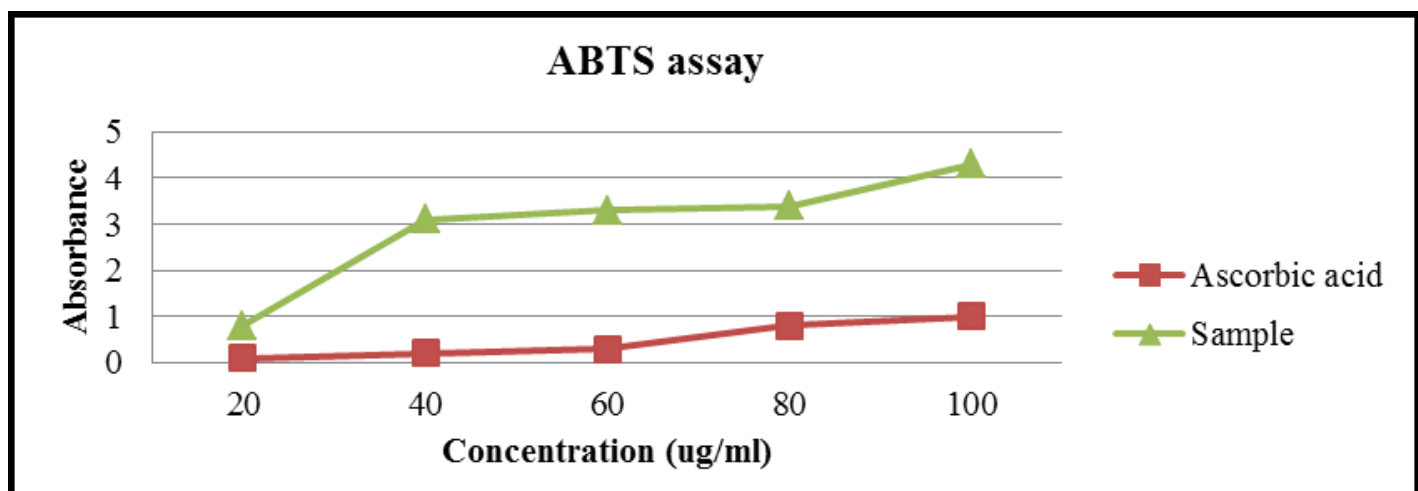

Figure 6-ABTS radical scavenging activity of Ethyl acetate extract of S.cumini

Table 10- Percentage of ABTS radical scavenging activity of Ethyl acetate extract of S.cumini

\begin{tabular}{|c|c|c|c|}
\hline \multirow{2}{*}{ S.No } & \multirow{2}{*}{$\begin{array}{l}\text { Concentration } \\
(\mathbf{u g} / \mathbf{m l})\end{array}$} & \multicolumn{2}{|c|}{$\%$ of ABTS radical scavenging activity } \\
\cline { 3 - 4 } & & Ascorbic acid & Sample \\
\hline 1 & 20 & 0.1 & 0.8 \\
\hline 2 & 40 & 0.2 & 3.1 \\
\hline 3 & 60 & 0.3 & 3.3 \\
\hline 4 & 80 & 0.8 & 3.4 \\
\hline 5 & 100 & 1.0 & 4.3 \\
\hline
\end{tabular}

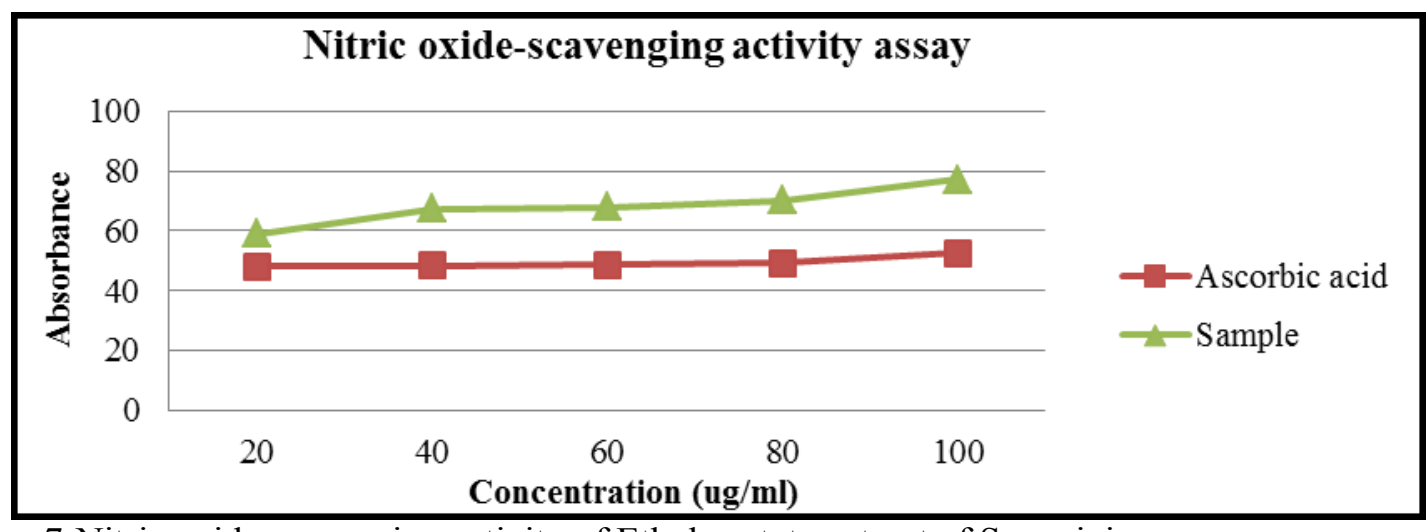

Figure 7-Nitric oxide scavenging activity of Ethyl acetate extract of S.cumini

Table 11- Percentage of Nitric oxide scavenging activity of Ethyl acetate extract of S.cumini

\begin{tabular}{|l|c|c|c|}
\hline S.No & \multirow{2}{*}{$\begin{array}{l}\text { Concentration } \\
\text { (ug/ml) }\end{array}$} & \% of nitric oxide scavenging activity \\
\cline { 3 - 4 } & 20 & Ascorbic acid & Sample \\
\hline 1 & 40 & 48.1 & 59.0 \\
\hline 2 & 60 & 48.2 & 67.2 \\
\hline 3 & 80 & 48.6 & 68.0 \\
\hline 4 & 100 & 49.1 & 70.1 \\
\hline 5 & 52.6 & 77.1 \\
\hline
\end{tabular}




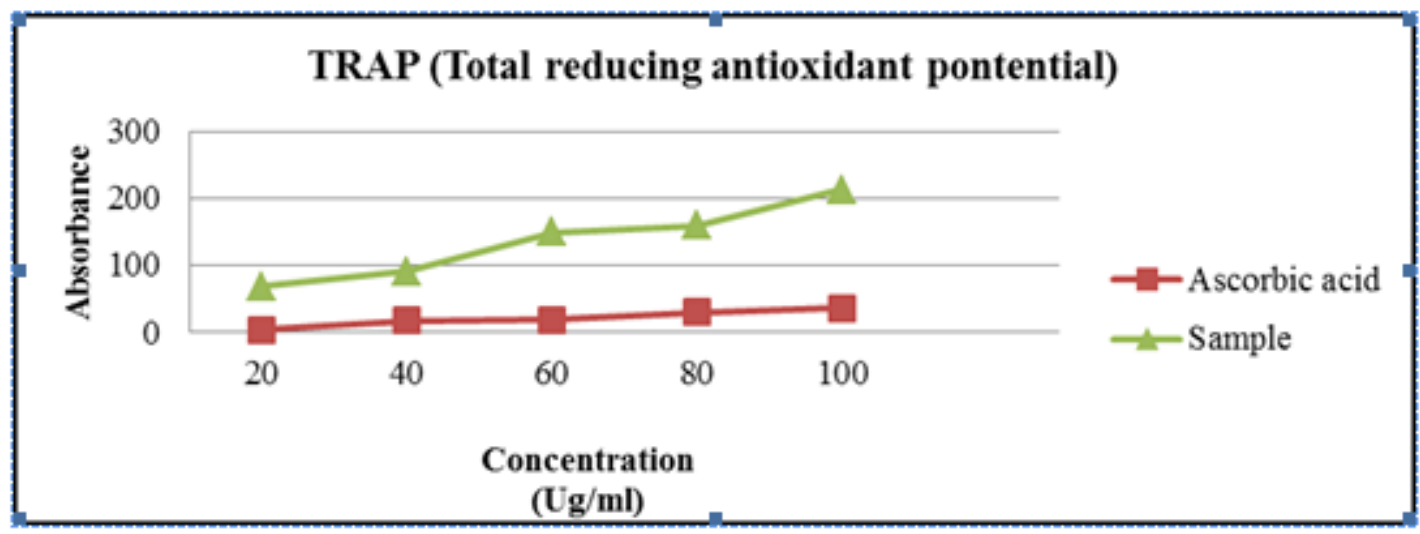

Figure 8-Total reducing antioxidant potential activity of Ethyl acetate extract of S.cumini

Table 12- Percentage of TRAP activity assay of Ethyl acetate extract of S.cumini

\begin{tabular}{|l|c|c|c|}
\hline S.No & \multirow{2}{*}{$\begin{array}{l}\text { Concentration } \\
\text { (ug/ml) }\end{array}$} & \% of inhibition \\
\cline { 3 - 4 } & 20 & Ascorbic acid & sample \\
\hline 1. & 40 & 3.125 & 68.75 \\
\hline 2. & 60 & 17.18 & 90.62 \\
\hline 3. & 80 & 29.68 & 150 \\
\hline 4. & 100 & 35.93 & 159.3 \\
\hline 5. & & & 212.5 \\
\hline
\end{tabular}

\section{CONCLUSION}

In the present study, the extracts prepared from dried seeds and leaves of the plant S.cumini were subjected to phytochemical screening, antibacterial activity and invitro antioxidant activity.

It was observed that the Ethyl acetate extract of S.cumini extended higher extractive value, when compared with Petroleum ether, Chloroform, Methanol and Water. Therefore Ethyl acetate extract was chosen for in depth study.

The Ethyl acetate extract of S.cumini was subjected to Thin layer chromotograpy using silica gel-G. The $\mathrm{R}_{\mathrm{f}}$ value were calculated and the study reveals the presence of Flavaloids, glycosides, Alkaloids, Steroids and Triterprioids .

The various phytochemical compounds detected are known to have beneficial importance in medicinal sciences. The flavonoids have been referred to as nature's biological response modifiers, because of their inherent ability to modify the body's reaction to allergies and virus and their anti-allergic, antiinflammatory, anti-microbial and anti-cancer activities(Aiyelaagbe and Osamudiamen, 2009). The steroids are known to be important for their cardiotonic activities and also insecticidal and antimicrobial properties. They are also used in nutrition, herbal medicine and cosmetics(Callow,1936). The Tannins were reported to exhibit antiviral, antibacterial and anti-tumour activities. It was also reported that certain tannins were able to inhibit HIV replication selectively and was also used as diuretic(Callow,1936). The Saponin is used as mild detergents and in intracellular histochemistal staining. It is also used to allow antibody access in intracellular proteins. In medicine, it is used in hypercholestrolaemia, hyperglycaemia, antioxidant, anticancer, antiinflammatory, weight loss, etc. It is also known to have antifungal properties(Haslem,1989).

In vitro antioxidant activity of the seed and leaf extract of Syzygium cumini was performed The results of different assays potrays that the extract has maximum antioxidant activity and reducing power. Hydroxyl radical scavenging activity of ethyl acetate extract of Syzygium cumini shows a steady state increase when compared to the standard ascorbic acid. All the other assays confirms the free radical scavenging activity of the extract.

\section{REFERENCES}

[1]. Abd El-Moneim M. R. Afify, Sayed A. Fayed, Emad A. Shalaby and Hany A. El-Shemy July 2011, Syzygium cumini (pomposia) active principles exhibit potent anticancer and antioxidant activities ,African Journal of Pharmacy and Pharmacology Vol. 5(7), 948-956

[2]. Patel Soncharan, Shanmugarajan T.S., Somasundaram. and Maity Niladri,2010., Protective effect of Syzygium cumini seeds against doxorubicin induced cardiotoxicity in rats International Journal Of Pharmacy \& Life ISSN: 0976-7126.

[3]. Nadkarni KM. 1954. In Indian Materia medica.,Popular book depot Bombay. 516-18. Vol. I. 
[4]. Aiyelaagbe O.O. and Osamudiamen P.M.2009.Phytochemical screening for active compounds in Mangifera indica, Plant, Sci. Res, 2(1), 11-13.

[5]. Banerjee A, Dasgupta N, De BB 2005. In vivo study of Antioxidant activity of S. cumini fruit. Food chemistry, 90, 727-33.

[6]. Benherlal PS, Arumughan C 2007. Chemical composition and in vitro antioxidant studies on Syzygium cumini fruit. J Sci Food Agric, 87, 2560-9.

[7]. Dorman HJD., Peltoketo A., Hiltunen R., Tikkanen MJ.2003.Characterisation of the antioxidant properties of deodourisation aqueous extracts from selected Lamiaceae Herbs. Food Chem. 83: 255-256.

[8]. Duh, P.D.; Tu, Y.Y.; Yen, G.C.1999, Antioxidant activity of water extract of Harng Jyur (Chrysanthemum morifolium Ramat). Leb-ensm. Wiss. Technol.32, 269-277.

[9]. Elizabeth K, Rao MNA, 1990, Oxygen radical scavenging activity of curcumin. Int J Pharmaceut, 58; 237-240.

[10]. Garratt DC: 1964.The quantitative analysis of Drugs. Volume 3. Chapman and Hall ltd, Japan; 456-458.

[11]. Gordon, MH .,1990, The mechanism antioxidant action in vitro. In food Antioxidants; Hudson, BJF, Ed. Elsevier Applied Science: London, UK, 1-18.

[12]. Green LC, Wagner DA, Glogowski J, Skipper PL, Wishnok JS, Tannenbaum SR .,1982. Analysis of nitrate, nitrite and 15N nitrate in biological fluids. Anal. Biochem. 126: 131-138.

[13]. Gupta GS, Sharma DP.,1974.Triterpenoid and other constituents of Eugenia jambolana leaves. Phytochemistry 13:2013-2014.

[14]. Halliwell B \& Gutteridge JMC. 1989. Free radicals in biology and medicine (2nd ed.). Oxford: Clarendon press. 1-32.

[15]. Kong, J.M., N.K. Goh, L.S. Chia and T.F.Chia. 2003. Recent advances in tradittional plant drugs and orchids.Acta Pharmacologica Sinica, 24(1): 7-21.

[16]. Kumar A, Ilavarasan R, Jayachandran T, 2008. Antiinflammatory activity of Syzygium cumini seed. Afr J Biotechnol, 7, 9413.133-42 Lett, 110, 41-8.30, 1932-40.

[17]. M. R. Sahaa, S. M. R. Hasana, R. Aktera, M. M. Hossaina, M. S. Alamb, M. A. Alama, and M. E. H. Mazumderc,2008. In vitro free radical scavenging activity of methanol extract of the leaves of mimusops elengi linn, department of Pharmacy, Stamford University Bangladesh, Dhaka, Bangl. J. Vet. Med. 6 (2): 197-202.

[18]. Manjeshwar Shrinath Baliga,2011. Anticancer, Chemopreventive and Radioprotective Potential of Black Plum (Eugenia Jambolana Lam), Asian Pacific Journal of Cancer Prevention, Vol 12.

[19]. Morton J. 1987.Jambolan. In: Morton JF (Ed) Fruits of warm climates. 375-378.

[20]. Muruganandan S, Srinivasan K, Chandra S, 2001. Antiinflammatory activity of Syzygium cumini bark. Fitoterapia, 72, 369-75.

[21]. Nair RAG.,1972. Flavonoids of the flowers of Eugenia jambolana. Curr Sci 41: 703-704

[22]. Muhammad Shahnawaz, Saghir Ahmed Sheikh , Muhammad Iqbal Bhangar and Ejaz Ahmed,2010. Total phenolic compounds and antioxidant activity of jamun fruit (Eugenia jambolana) products, 1 Institute of Food Science \& Technology, Sindh Agriculture University Tandojam, Pakistan Journal of Food Sciences Volume 20, Issue 1-4, Page(s): 31-41.

[23]. Nazmul Ahsan, Nilanjana Paul, Nazrul Islam and Anwarul A. Akhand,2012. Leaf Extract of Syzygium cumini Shows Anti-Vibrio Activity Involving DNA Damage, Department of Genetic Engineering and Biotechnology, University of Dhaka, Dhaka-1000, Dhaka Univ. J. Pharm. Sci. 11(1): 25-28.

[24]. Abhishek Kumar Sah and Vinod K. Verma 2011.Addition to mycoflora of Syzygium cumini from Pakistan Syed Quaiser Abbas and Sobia Mushtaq ,Department of Botany, Government College University, Faisalabad, J. Chem. Pharm. Res., 3(3):108-113.

[25]. Oliver.B, 1880, Oral hypoglycaemic plants in west Africa, J.Ethnopharmacol,2:119-127.

[26]. Oyaizu M.,1986, Studies on products of browning reactions: antioxidant activities of products of browning reaction prepared from glucose amine. Jap J Nutr 44:307-315. 